\title{
Properties and Substrate Specificities of Four Esterases from Aspergillus niger NRRL $337^{\dagger}$
}

\author{
Susumu OKumura, Mieko Iwai and Yoshio Tsujisaka \\ Osaka Municipal Technical Research Institute, Osaka 536, Japan \\ Received February 9, 1983
}

\begin{abstract}
Properties and substrate specificities of four esterases (Esterase-I, -II, -III, -IV) from Aspergillus niger were studied. Esterase-I and Esterase-II were found to be markedly stable to heat. When Esterase-I was assayed at $35^{\circ} \mathrm{C}$ using methylacetylsalicylate as a substrate, even after heating at $100^{\circ} \mathrm{C}$ for $15 \min 60 \%$ of its activity remained. However, Esterase-I scarcely hydrolyzed the substrate at $70^{\circ} \mathrm{C}$ or over, because of a reversible change in conformation by heating as found by $\mathrm{CD}$ measurement. The maximum activity of Esterase-I was found at $55^{\circ} \mathrm{C}$ at $20 \mathrm{~min}$ of reaction time. Esterase-II was stable up to $80^{\circ} \mathrm{C}$ and had an optimum temperature for reaction at $80^{\circ} \mathrm{C}$, but was irreversively inactivated by heating for $15 \mathrm{~min}$ at $90^{\circ} \mathrm{C}$.

The four esterases hydrolyzed aliphatic esters of short chain fatty acids and acetyl esters of phenols, but neither methyl esters of aromatic carboxylic acids nor acetyl esters of aromatic alcohols.
\end{abstract}

Many studies on carboxylesterase (EC 3. 1. 1. 1) from animal sources have been carried out, and it has been reported that plural esterases are present in liver, ${ }^{1,2)}$ serum $^{3)}$ or other tissues, ${ }^{4,5)}$ as so-called isoenzymes. Recently, characterization of individual esterases belonging to isoenzymes from animal sources has been attempted, to clarify the mechanism of formation of complicated isoenzymes. $^{1 \sim 3)}$ However, no detailed studies of isoenzymes or multiple formes of microbial esterases have been presented.

In the preceding paper, we described the purification of esterases from Aspergillus niger NRRL 337 and showed that Aspergillus niger produced four kinds of esterases. ${ }^{6)}$ In the present paper, characterization of these four esterases from Aspergillus niger is described as a further contribution to clarify the mechanism of the production of multiple forms of microbial esterases.

\section{MATERIALS AND METHODS}

Esterase preparations. Four esterases (Esterase-I, -II, -III, -IV) were purified to homogeneity according to the procedures described in the preceding paper. ${ }^{6)}$

Esterase assay. Esterase activity was assayed as described previously ${ }^{6)}$ and 1 unit (U) was defined as the activity which liberated $1 \mu \mathrm{mol}$ equivalent of methylsalicylate per min from methylacetylsalicylate.

Circular dichroism measurement. Circular dichroism (CD) spectra in the 200 to $250 \mathrm{~nm}$ region were measured on a model J-500 with DP-500 dataprocessor (JASCO, Japan) using a water-jacketed cell of $0.5 \mathrm{~mm}$ path length. Optical density at $280 \mathrm{~nm}$ of the sample was $0.3 / \mathrm{cm}$.

Analysis of reaction products. Products released from methylacetylsalicylate by the action of the esterases were separated using a high performance liquid chromatography (HPLC) RP-18 column (E. Merck, $4 \times 150 \mathrm{~cm}$, methanol- $1 \%$ acetic acid $4: 6 \mathrm{v} / \mathrm{v}$ ) and detected by UV absorption at $290 \mathrm{~nm}$.

Hydrolysis of various esters. A reaction mixture consisting of $0.5 \mathrm{~g}$ of ester, $5 \mathrm{ml}$ of $0.02 \mathrm{M}$ phosphate buffer $(\mathrm{pH} 7)$ for Esterase-I and Esterase-II or $5 \mathrm{ml}$ of $0.05 \mathrm{M}$ acetate buffer (pH 5) for Esterase-III and Esterase-IV, and $1 \mathrm{ml}$ of enzyme solution ( $1 \mathrm{U}$ ) was stirred at $500 \mathrm{rpm}$ for $1 \mathrm{hr}$ at $45^{\circ} \mathrm{C}$. The reaction was stopped by adding $20 \mathrm{ml}$ of ethanol and liberated acid was titrated with $0.05 \mathrm{M} \mathrm{KOH}$.

Reagents. Various esters were products of Tokyo Kasei Kogyo Co. Other reagents were purchased from Wako Pure Chemicals Co.

\footnotetext{
$\dagger$ Studies on microbial esterases. Part II. For Part I, see ref. 6.
} 
Table I. Properties of Four Esterases from Aspergillus niger

The activity was assayed on methylacetylsalicylate as described in METHODS.

\begin{tabular}{lcccc}
\hline & Esterase-I & Esterase-II & Esterase-III & Esterase-IV \\
\hline $\begin{array}{l}\text { Optimum pH } \\
\left(35^{\circ} \mathrm{C}, 20 \text { min reaction }\right)^{a}\end{array}$ & 7.0 & 7.5 & 5.5 & 4.5 \\
$\begin{array}{l}\text { pH stability } \\
\left(30^{\circ} \mathrm{C}, 16 \mathrm{hr} \text { incubation }\right)^{b}\end{array}$ & $6 \sim 12.3$ & $3 \sim 9$ & $4 \sim 8$ & $4 \sim 8$ \\
$\begin{array}{l}\text { Optimum temperature } \\
(20 \text { min reaction at opt. pH) }\end{array}$ & $55^{\circ} \mathrm{C}$ & $80^{\circ} \mathrm{C}$ & $55^{\circ} \mathrm{C}$ & $45^{\circ} \mathrm{C}$ \\
$\begin{array}{l}\text { Thermal stability } \\
(15 \text { min incubation at opt. } \mathrm{pH})\end{array}$ & $\begin{array}{c}55^{\circ} \mathrm{C}(100 \%)^{d} \\
100^{\circ} \mathrm{C}(60 \%)\end{array}$ & $\begin{array}{l}80^{\circ} \mathrm{C}(100 \%) \\
90^{\circ} \mathrm{C}(0 \%)\end{array}$ & $\begin{array}{l}50^{\circ} \mathrm{C}(100 \%) \\
70^{\circ} \mathrm{C}(0 \%)\end{array}$ & $\begin{array}{l}45^{\circ} \mathrm{C}(100 \%) \\
60^{\circ} \mathrm{C}(0 \%)\end{array}$ \\
\hline
\end{tabular}

a $\quad 0.2 \mathrm{M} \mathrm{Na} \mathrm{NPO}_{4}-0.1 \mathrm{M}$ citric acid buffer was used.

$b \quad 0.2 \mathrm{M} \mathrm{Na}_{2} \mathrm{HPO}_{4}-0.1 \mathrm{M}$ citric acid buffer $(\mathrm{pH} 2.5 \sim 8)$ and $0.1 \mathrm{M}$ glycine- $-0.1 \mathrm{M} \mathrm{NaOH}$ buffer $(\mathrm{pH} 8.5 \sim 13)$ were used.

c After the heat treatment, the enzyme solution was cooled at $0^{\circ} \mathrm{C}$ for $5 \mathrm{~min}$, and activity was measured.

d Relative residual activity after treatment at each temperature is shown in parentheses.

\section{RESULTS AND DISCUSSION}

\section{Enzymatic properties}

The effects of $\mathrm{pH}$ and temperature on enzyme activity were examined using methylacetylsalicylate as substrate, and the results are summarized in Table I. Esterase-I and Esterase-II were stable in the wide ranges of pH $6 \sim 12.6$ and $\mathrm{pH} 3 \sim 9$, respectively. The maximum activities of Esterase-I and EsteraseII were found at around neutral $\mathrm{pH}$, while those of Esterase-III and Esterase-IV were found at acidic $\mathrm{pHs}$.

Esterase-II was not inactivated by temperatures up to $80^{\circ} \mathrm{C}$ during incubation for $15 \mathrm{~min}$, and had an optimum temperature of $80^{\circ} \mathrm{C}$. In contrast, Esterase-I had an optimum temperature of $55^{\circ} \mathrm{C}$ and scarcely hydrolyzed the substrate over $70^{\circ} \mathrm{C}$. However, $60 \%$ of its activity remained when it was measured at $35^{\circ} \mathrm{C}$ after heating at $100^{\circ} \mathrm{C}$ for $15 \mathrm{~min}$. It is presumed that this is because of a reversible change of conformation. To prove this assumption, the change in conformation of Esterase-I at high temperature was examined by $\mathrm{CD}$ measurement. As shown in Fig. 1-A, a marked change in conformation of the enzyme was observed during the rise of temperature from $15^{\circ} \mathrm{C}$ to $75^{\circ} \mathrm{C}$, that is, a random coil was formed as a result of loosening of $\alpha$-helix by heating.
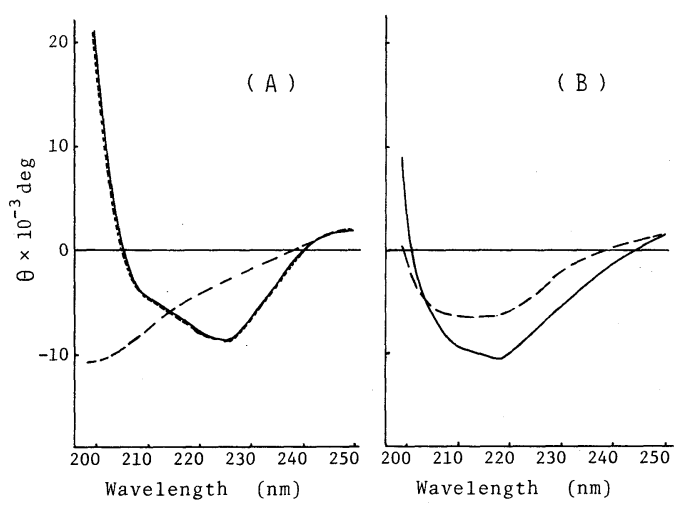

FIG. 1. CD Spectra of Native and Heat-treated Esterases.

A Esterase-I: - - measured at $15^{\circ} \mathrm{C}$;----, measured at $75^{\circ} \mathrm{C} ;-\cdots--$, measured at $15^{\circ} \mathrm{C}$ after heating at $75^{\circ} \mathrm{C}$ for 15 $\min$.

B Esterase-II: -, measured at $15^{\circ} \mathrm{C},---$, measured at $15^{\circ} \mathrm{C}$ after heating at $90^{\circ} \mathrm{C}$ for $15 \mathrm{~min}$.

However, cooling the enzyme solution from $75^{\circ} \mathrm{C}$ to $15^{\circ} \mathrm{C}$, the spectrum coincided with that of native enzyme. In addition, the remaining activity of Esterase-I which had been cooled after heating at $75^{\circ} \mathrm{C}$ for $15 \mathrm{~min}$ was $95 \%$ of that of native enzyme. From the results described above, we concluded that Esterase-I changed its conformation by heating at $75^{\circ} \mathrm{C}$ and so was inactivated, but the conformation and activity are immediately restored by cool- 
ing. The CD spectra of Esterase-II (Fig. 1-B) showed that Esterase-II was irreversibly denaturated by heating at $90^{\circ} \mathrm{C}$ for $15 \mathrm{~min}$.

As it is well known that carboxylesterases from animal sources have serine residues at their active site, ${ }^{5)}$ the effects of diisopropyl fluorophosphate (DFP) on the activities of the four esterases were investigated. A mixture consisting of $0.5 \mu \mathrm{mol}$ of DFP and $0.02 \mu \mathrm{mol}$ of enzyme was incubated at $20^{\circ} \mathrm{C}$. After $20 \mathrm{~min}$, remaining activity was assayed. Activities of all the esterases tested were strongly inhibited by DFP. The results suggest that a serine residue is present in the a- ctive site or substrate binding site of the esterases, as in the esterases of animal tissues.

\section{Substrate specificity}

The action of the four esterases on methyl esters of fatty acids and triacylglycerols are shown in Table II. They hydrolyzed only the esters of short chain fatty acids (C2-C4) except that Esterase-II also hydrolyzed methyl esters of medium chain fatty acids (C6$\mathrm{C} 10)$. None of the esterases hydrolyzed esters of long chain fatty acids, e.g. olive oil, tristearin, methyloleate or methylpalmitate.

Table III summarized the extent of hy-

Table II. Hydrolysis of Fatty Acid Esters by Four Esterases FROM Aspergillus niger

Experimental conditions are described in the text. After the reaction, liberated fatty acids were titrated with $0.05 \mathrm{M} \mathrm{KOH}$. End point of titration was $\mathrm{pH} 8$.

\begin{tabular}{llccc}
\hline \multicolumn{1}{c}{ Substrate } & Esterase-I & Esterase-II & Esterase-III & Esterase-IV \\
\hline & & $0.05 \mathrm{M} \mathrm{KOH} \mathrm{(ml)}$ & 0.1 & 1.2 \\
Methylacetate & 0.5 & 0.1 & 0.9 & 0.2 \\
Methylpropionate & 1.0 & 0.1 & 0.2 & 0.1 \\
Methylbutyrate & 0.6 & 0.1 & 0 & 0 \\
Methylcaproate & 0.4 & 0.4 & 0 & 0 \\
Methylcaplyrate & 0.1 & 2.1 & 0 & 0 \\
Methylcaprate & 0 & 0.6 & 1.6 & 3.4 \\
Triacetin & 2.0 & 0.2 & 0.4 & 0.1 \\
Tripropionin & 1.9 & 1.1 & 0.4 & 0.1 \\
Tributyrin & 0.3 & 1.4 & 0.2 & 0 \\
Tricaproin & 0 & 0.3 & 0 & 0 \\
Tricaplyrin & 0 & 0 & 0 & 0 \\
Tricaprin & 0 & 0 & & \\
\hline
\end{tabular}

Table III. Hydrolysis of Aromatic Esters by Four Esterases FROM Aspergillus niger

Experimental conditions are described in the text. After the reaction liberated fatty acids were titrated with $0.05 \mathrm{M} \mathrm{KOH}$. End point of titration was $\mathrm{pH} 7$.

\begin{tabular}{|c|c|c|c|c|}
\hline Substrate & Esterase-I & Esterase-II & Esterase-III & Esterase-IV \\
\hline \multicolumn{5}{|c|}{0.05 м KOH (ml) } \\
\hline Methylacetylsalicylate & 1.1 & 3.5 & 2.7 & 1.0 \\
\hline Phenylacetate & 2.0 & 2.1 & 1.5 & 0.9 \\
\hline$\alpha$-Naphthylacetate & 0.5 & 0.3 & 0 & 0 \\
\hline$\beta$-Naphthylacetate & 0 & 0 & 0 & 0 \\
\hline Benzylacetate & 0 & 0 & 0 & 0 \\
\hline$\beta$-Phenethylacetate & 0 & 0 & 0 & 0 \\
\hline Methylsalicylate & 0 & 0 & 0 & 0 \\
\hline Methylbenzoate & 0 & 0 & 0 & 0 \\
\hline
\end{tabular}


drolysis of various aromatic esters by the esterases. All four esterases hydrolyzed acetyl esters of phenols (phenylacetate, methylacetylsalicylate) but not methyl esters of aromatic carboxylic acids (methylbenzoate, methylsalicylate) or acetyl esters of aromatic alcohols (benzylacetate, $\beta$-phenethylacetate). Esterase-I and Esterase-II hydrolyzed $\alpha$-naphthylacetate but Esterase-III and Esterase-IV did not. The action of Esterase-I and Esterase-II on several substrates other than the compounds shown in Table II was investigated. Among them, $o$ cresolacetate, $m$-cresolacetate, $p$-cresolacetate, $p$-nitrophenylacetate and resocinoldiacetate were hydrolyzed by Esterase-I and Esterase-II, as well as phenylacetate. Acetylcholine and $p$ nitrophenylphosphate were not hydrolyzed by any of the four esterases.

The specificity of each esterase on the two ester bonds of methylacetylsalicylate was investigated. Each esterase was allowed to react with methylacetylsalicylate, and part of the reaction mixture was injected directly onto HPLC at different reaction times. The products were identified by their retention times. Only methylsalicylate was detected, and acetylsalicylate and salicylic acid were not found at any stage of the reaction. In this manner, it was revealed that the four esterases cleaved only the acetyl bond of methylacetylsalicylate and did not cleave the methyl bond. This result agreed with the data shown in Table III.

As described above, the four esterases from
Aspergillus niger hydrolyzed not only aliphatic esters (Table II) which are the usual substrates for carboxylesterases (EC 3. 1. 1. 1) but also aromatic esters (Table III) which are the substrates for arylesterases (EC 3. 1. 1. 2). This is an example of the ambiguity of the present classification of esterases, as pointed out also by Krish. $^{5)}$ However, according to the presently-used nomenclature system, these four esterases from Aspergillus niger appear to be classified as carboxylesterases, because most of the animal esterases which can hydrolyze both aliphatic and aromatic esters have been so classified.

Acknowledgment. The competent assistance of Mrs. Elizabeth L. de Leal and Dr. Sirirat Sarawek is gratefully acknowledged. We thank Dr. Akio Sugihara for the measurement of the CD spectrum.

\section{REFERENCES}

1) E. Heymann and W. Junge, Eur. J. Biochem., 95, 509 (1979).

2) M. T. C. Runneger, K. Scott, E. C. Webb and B. Zerner, Biochem., 8, 2013 (1969).

3) J. Otto, A. Ronai and O. Deimling, Eur. J. Biochem., 116, 285 (1981).

4) A. Göppinger, M. Riebschläger, A. Ronai and O. Deimling, Biochim. Biophys. Acta, 525, 75 (1978).

5) K. Krisch, "The Enzymes," Vol. V, ed. by P. D. Boyer, Academic Press Inc., New York N. Y., 1971, pp. $43 \sim 69$.

6) M. Iwai, S. Okumura and E. L. de Leal and Y. Tsujisaka, Agric. Biol. Chem., 47, 1865 (1983). 